\title{
David Thomas Jones, C.B.E.
}

David Thomas Jones was born at Gilfachgoch, Glamorgan, on 10th June 1866, and early determined to make the Civil Service his career in life. At the age of twenty-one he was posted as a junior clerk to the staff of the Fishery Board for Scotland, and only five years later he became the Chief Clerk. In 1909 he was promoted to be Secretary, which appointment he held all through the troubled years of the War when the Board's cruisers were taken into Admiralty service and he became a PaymasterLieutenant-Commander in the Royal Naval Reserve. It was during the War that Mr Jones consolidated his position in the Civil Service and fishery world, and brought to bear on the many problems which then arose the experience which he had gained and the judgment which he had matured during his earlier service. Only by an intimate knowledge of the fishing industry and population and, as he himself most readily admitted, by the willing co-operation of those under his command, was he able to advise on the urgent and sometimes far-reaching problems which then arose. From Mr Jones came the advice on which the Fishery Board decided the fishermen who might be taken for the country's war service and those who might be left to augment in such necessary fashion the war food supplies. He had to adjust as far as might be possible the insistent needs of war action with those other almost equally insistent needs of continuing to obtain fish supplies for an ever-ready market. No less after the War were his services in demand on various committees of reorganisation, and later he was deputed to visit and report on the suitability of the coast of British Columbia for the settlement of crofter fishermen from the Western Highlands and Islands. For his war services he was awarded the honour of C.B.E.

In $1920 \mathrm{Mr}$ Jones was made Chairman of the Fishery Board and thus achieved the then most unusual distinction of passing through all the administrative grades in one department from the most junior to the senior post. Perhaps, however, the achievement of which Mr Jones was most proud was that he held Commissions from three different sovereigns in the three services-the Navy, the Army, and the Civil Service. An enthusiastic Volunteer, he served with the Royal Scots as long as age and his other duties permitted, and retired with the rank of Captain.

Keenly interested as he was in the practical side of sea-fishery 
matters, Mr Jones was by no means blind to the necessity of theory and investigation. It was mainly under his chairmanship that the development of the Marine Research staff and the laboratory of the Board at Aberdeen took place, and he was one of the British Delegates to the International Council for the Exploration of the Sea. It was owing to his encouragement and advice on the administrative side, and due to the manner in which he sponsored the applications for the necessary funds, that the scientists under the charge of $\mathrm{Dr}$ Bowman have been able to take the place in international deliberations which is now accorded them, and to receive the consideration which their achievements merit. The author of a number of papers on fishery subjects, he was elected a Fellow of the Society in 1924, and was also a Fellow of the Royal, Statistical Society.

At first a stranger to Scotland, Mr Jones, by his personality and accomplishments, quickly made himself at home and his presence appreciated wherever he went. An accomplished musician, with a deep affection more particularly for the older and more simple melodies, he was for long a member, and for a time the President, of the Edinburgh Harmonists Society, of which a predecessor in the fishery connection, Gilbert Innes of Stow, was the founder. A Freemason, a golfer, a bowler, and of a genial social disposition, Mr Jones had a very wide circle of friends and a still larger number of acquaintances who mourn the loss of one keenly interested in all that went on around, and who was always willing to help others in need with assistance and advice. His death on 4th February 1931 is the more tragic, in that it occurred within a very few months of the time when he was looking forward to some rest and recreation free from the cares of his long official life. His wife predeceased him by a few years and three daughters survive.

W. J. M. M. 